\title{
Electrochemical reduction of dehydroamino acids: Synthesis and photophysical properties of $\beta, \beta$-diarylalanines
}

\author{
Paula M.T. Ferreira ${ }^{\mathrm{a}}{ }^{*}$ Luís S. Monteiro $^{\mathrm{a}, *}$ Elisabete M.S. Castanheira $^{\mathrm{b}}$, Goreti Pereira ${ }^{\mathrm{a}}$, Carla Lopes $^{\mathrm{a}}$ and \\ Helena Vilaça ${ }^{\mathrm{a}}$
}

${ }^{a}$ Chemistry Centre (CQ-UM), University of Chemistry, Campus de Gualatr, 4710-057 Braga, Portuga

${ }^{b}$ Centre of Physics (CFUM), University of Minho, Campus de Gualtar, 4710-057 Braga, Portugal

\section{ARTICLE INFO}

Article history:

Received

Received in revised form

Accepted

Available online

Keywords:

Dehydroamino acids

Reduction

Cyclic voltammetry

Electrolysis

$\beta, \beta$-diarylalanines

\section{ABSTRACT}

Several $\beta, \beta$-disubstituted dehydroalanines were prepared from $\beta, \beta$-dibromo or $\beta$-bromo, $\beta$ substituted dehydroalanines and aryl boronic acids using a Suzuki-Miyaura cross-coupling reaction. The electrochemical behaviour of these compounds was studied by cyclic voltammetry. All compounds studied showed similar reduction potentials and these were similar to the peak potential of the methyl ester of $N$-tert-butoxycarbonyl dehydrophenylalanine. Thus, the presence of a second aryl moiety in the dehydroalanine scaffold does not significantly change the reduction potential.

Controlled potential electrolysis were preformed at the cathodic peak potential in the presence of triethylammonium chloride as proton donor. The only products isolated in good to high yields were the corresponding $\beta, \beta$-diarylalanines. This reaction was also carried out using a dipeptide containing a $\beta, \beta$-diaryldehydroalanine to give a 1:1 diastereomeric mixture of the reduction product.

The photophysical properties of two of the $\beta, \beta$-diaryldehydroalanines and of the corresponding $\beta, \beta$-diarylalanines were studied in three solvents of different polarity. The $\beta, \beta$ diaryldehydroalanines show low fluorescent quantum yields $\left(\Phi_{\mathrm{F}}<9 \%\right)$ due to the conjugation of the aromatic moieties with the $\alpha, \beta$-double bond and with the carbonyl group, which favours the non-radiative deactivation pathways. The absence of conjugation in the reduction products leads to a significant increase in the fluorescence quantum yields. These results show that the $\beta, \beta$ disubstituted alanines could be used as fluorescent markers.

2009 Elsevier Ltd. All rights reserved.

\section{Introduction}

The reduction of an isolated double bond is not possible using electrochemical methods, however when the double bond is conjugated with an electron withdrawing group such as a carbonyl it becomes reducible in the accessible potential range. ${ }^{1}$ This can be explained by the fact that conjugation lowers the energy of the lowest unoccupied $\pi$-orbital which results in a less negative reduction potential. There are a few reports on the electrochemical reduction of activated alkenes such as $\alpha, \beta$ unsaturated ketones. ${ }^{2}$ In these studies it was demonstrated that the electrochemical reduction of unsaturated ketones involves an initial electron transfer to the ketone producing a radical anion which undergoes protonation followed by other chemical or electrochemical processes. ${ }^{2}$ Thus, the radical anion may dimerize or it can be reduced to give the saturated ketone. ${ }^{1,2}$

For some years now we have been interested in the synthesis of dehydroamino acid derivatives and in using these compounds as substrates in several types of reactions. ${ }^{3}$ As part of this work we have been studying the electrochemical behaviour of dehydroamino acid derivatives. Thus, it was possible to develop an efficient method for the synthesis of 2,5diaminoadipic acid derivatives by controlled potential electrolysis of $\mathrm{N}, \mathrm{N}$-diprotected dehydroalanines. ${ }^{4}$ Recently we investigated the electrochemical behaviour of $\beta$ halodehydroamino acids and found that these compounds show higher reduction potentials when compared with those of the corresponding dehydroamino acids. ${ }^{5}$ Controlled potential electrolysis of the former afforded the $E$-isomers of the dehalogenated dehydroamino acids. Although there are many reports concerning the chemical reduction of $\alpha, \beta$ dehydroamino acids, ${ }^{6}$ to the best of our knowledge the electrochemical reduction of $\beta, \beta$-disubstituted dehydroamino acids has not yet been described. Since dehydroamino acids can be considered activated alkenes we decided to study the electrochemical reduction of $\beta, \beta$-disubstituted dehydroalanines obtained by a Suzuki-Miyaura cross-coupling from $\beta$ halogenated dehydroamino acids and arylboronic acids. The photophysical properties of some of the saturated amino acids prepared were evaluated in solvents of different polarity and compared with those of the corresponding $\beta, \beta$ diaryldehydroalanines. 


\section{Results and discussion}

Several $\beta, \beta$-diaryldehydroalanines were prepared from a $\beta, \beta$-dibromoalanine ${ }^{7}$ or from a $\beta$-bromodehydrophenylalanine ${ }^{3 \mathrm{~d}}$ and aryl boronic acids by a Suzuki-Miyaura coupling reaction (Scheme 1). ${ }^{8}$<smiles>[R]C(Br)=C(NP)C(C)=O</smiles>

$\mathrm{P}=\mathrm{Boc}, \mathrm{R}=\mathrm{Br} ; \mathbf{1}$ $\mathrm{P}=\mathrm{Boc}, \mathrm{R}=\mathrm{Ph} ; 2$

$\mathrm{P}=\mathrm{Boc}-\mathrm{L}-\mathrm{Phe}, \mathrm{R}=\mathrm{Ph} ; \mathbf{3}$

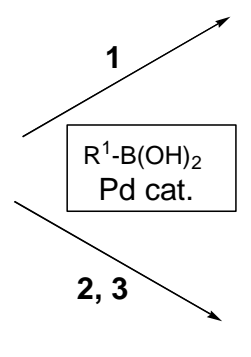<smiles>[R]C([Ge]Cl)=C(NC(C)(C)C)C(C)=O</smiles><smiles>CC(=O)C(NP)=C(P)c1ccccc1</smiles>

$\mathrm{P}=\mathrm{Boc} ; 5 \mathrm{c}$ $\mathrm{P}=$ Boc-L-Phe; $6 \mathrm{a}$
$\mathrm{R}^{1}=$<smiles>Cc1ccccc1</smiles>

$\mathbf{a}$<smiles>Cc1ccc(-c2ccccc2)cc1</smiles>

b;<smiles>Cc1cccc2ccccc12</smiles>

c;<smiles>Cc1ccc2c3c(cccc13)CC2</smiles>

Scheme 1

Cathodic peak potentials of compounds $4 \mathbf{a}-\mathbf{d}, \mathbf{5 c}$ and $\mathbf{6 a}$ were measured by cyclic voltammetry at a vitreous carbon electrode in dimethylformamide containing $0.1 \mathrm{~mol}^{-\mathrm{dm}^{-3}}$ of $\mathrm{Bu}_{4} \mathrm{NBF}_{4}$ as supporting electrolyte (Table 1). All cyclic voltammetry plots were irreversible which may be due to a rapid chemical reaction of the radical anion formed in the first electron transfer. An identical feature was reported for the reduction of 1,3-diphenyl-2-propen-1-ones (chalcones). ${ }^{2}$ From the cathodic peak potentials presented in Table 1 it is possible to observe that all compounds studied have similar reduction potentials. Also when these potentials are compared with that of the methyl ester of $N$-tertbutoxycarbonyldehydrophenylalanine (Boc- $\Delta$ Phe-OMe, -1.84 $\mathrm{V} v s$ ECS $)^{4}$ it can be concluded that the presence of a second aryl moiety at the $\beta$-carbon atom does not significantly influence the reduction potential.

The next step in our investigation was to attempt the electrochemical reduction of the $\alpha, \beta$-double bond in the dehydroamino acid framework. Thus, compounds $\mathbf{4 a - d , ~ 5 c}$ and 6a were submitted to controlled potential electrolysis in acetonitrile using $\mathrm{Et}_{4} \mathrm{NCl}\left(0.1 \mathrm{~mol} . \mathrm{dm}^{-3}\right)$ as supporting electrolyte and $\mathrm{Et}_{3} \mathrm{NHCl}\left(0.04 \mathrm{~mol}_{\mathrm{Nm}}{ }^{-3}\right)$ as proton donor (Scheme 2). It was found that the only products isolated were the corresponding $\beta, \beta$-diarylalanines (7a-d, 8c and 9a) in good to high yields (Table 2). This result is different from those reported for $\alpha, \beta$-unsaturated ketones and $N, N$-diprotected dehydroalanines. In the case of $\alpha, \beta$-unsaturated ketones the reduction products include the saturated ketone and a dimer. ${ }^{1,2}$ $N, N$-diprotected dehydroalanines give upon electrochemical reduction the corresponding diamino dicarboxylic acids. ${ }^{4}$

${ }^{1} \mathrm{H}$ NMR spectra of compounds 7a-d clearly show the presence of two signals, one doublet between 4.38 and 6.12 ppm and a broad triplet between 5.08 and $5.31 \mathrm{ppm}$, originated from the $\beta$ - and $\alpha-\mathrm{CH}$ protons of the alanine derivatives. Also in the ${ }^{13} \mathrm{C}$ NMR spectra it is possible to observe the presence of two signals between 42.40 and $57.01 \mathrm{ppm}$ that correspond to the $\alpha-C$ and $\beta-C$ atoms of the saturated system. In the case of compounds $\mathbf{5 c}$ and $\mathbf{6 a}, 1: 1$ diastereomeric mixtures were obtained showing that, as expected, the reaction is not stereoselective.

Table 1. Cathodic peak potentials obtained by cyclic

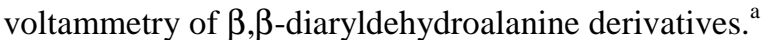<smiles>COC(=O)C(NC(=O)OCc1ccccc1)=C(c1ccc(-c2ccccc2)cc1)c1ccc2ccccc2c1/C(=C(/NC(=O)OCc1ccccc1)C(=O)OC)c1cccc2ccccc12</smiles>

${ }^{a}$ Cathode: vitreous carbon. Solvent: dimethylformamide. Supporting electrolyte: $\mathrm{Bu}_{4} \mathrm{NBF}_{4} 0.1 \mathrm{~mol} \mathrm{dm}{ }^{-3}$. Substrate conc.: $\approx 0.005 \mathrm{~mol} \mathrm{dm}^{-3}$. 
<smiles>[2H]C=C(NP)C(=O)[O-]</smiles>

$\mathrm{P}=\mathrm{Boc} ; \mathbf{4 a - d ,} 5 \mathrm{c}$.

$\mathrm{P}=\mathrm{Boc}-\mathrm{L}-\mathrm{Ph}$; 6 .

Scheme 2

Table 2. Results obtained in the controlled potential electrolysis of $\beta, \beta$-diaryldehydroalanine derivatives. ${ }^{a}$

\begin{tabular}{|c|c|c|}
\hline Substrate & Product & Yield/\% \\
\hline $4 a$ & $\begin{array}{l}\text { Methyl 2-(tert-butoxycarbonylamino)- } \\
\text { 3,3-diphenylpropanoate, 7a }\end{array}$ & 85 \\
\hline $4 b$ & $\begin{array}{l}\text { Methyl 3,3-di(biphenyl-4-yl)-2-(tert- } \\
\text { butoxycarbonylamino)propanoate, 7b }\end{array}$ & 79 \\
\hline $4 c$ & $\begin{array}{l}\text { Methyl 2-(tert-butoxycarbonylamino)- } \\
\text { 3,3-di(naphthalen-1-yl)propanoate, 7c }\end{array}$ & 81 \\
\hline $4 d$ & $\begin{array}{l}\text { Methyl 2-(tert-butoxycarbonylamino)- } \\
\text { 3,3-bis(1,2-dihydroacenaphthylen-5- } \\
\text { yl)propanoate, 7d }\end{array}$ & 78 \\
\hline $5 c$ & $\begin{array}{l}\text { Methyl 2-(tert-butoxycarbonylamino)- } \\
\text { 3-(naphthalen-1-yl)-3- } \\
\text { phenylpropanoate, 8c }\end{array}$ & 76 \\
\hline $6 a$ & $\begin{array}{l}\text { Methyl 2-[(S)-2-(tert-butoxycarbonyl } \\
\text { amino)-3-phenylpropanamido]-3,3- } \\
\text { diphenylpropanoate, 9a }\end{array}$ & 86 \\
\hline
\end{tabular}

${ }^{\text {a }}$ Cathode: vitreous carbon. Solvent: acetonitrile. Supporting electrolyte: $\mathrm{Et}_{4} \mathrm{NCl}\left(0.1 \mathrm{~mol} \mathrm{dm}^{-3}\right) ; \mathrm{Et}_{3} \mathrm{NHCl}\left(0.04 \mathrm{~mol} \mathrm{dm}^{-3}\right)$.<smiles>[R]CC(NP)C(C)=O</smiles>

$\mathrm{P}=\mathrm{Boc} ; \mathbf{7 a - d}, \mathbf{8 c}$. $\mathrm{P}=\mathrm{Boc}-\mathrm{L}-\mathrm{Phe} ; \mathbf{9 a}$

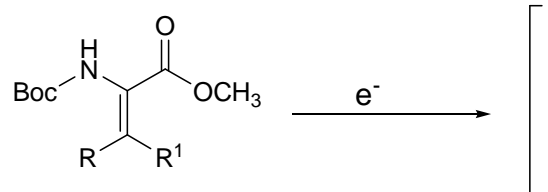<smiles>[2H]C=C(NC(=O)c1ccccc1)C(=O)OC</smiles>

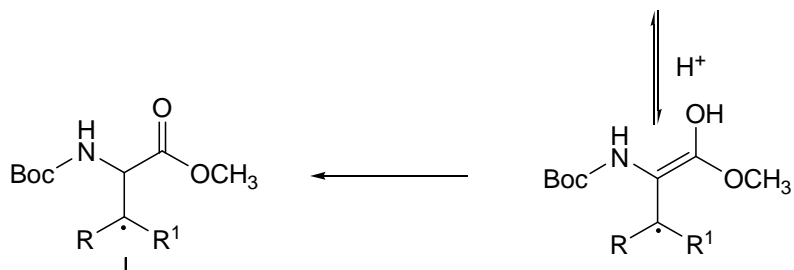
$\mathrm{e}^{-/ \mathrm{H}^{+}}$<smiles>COC(=O)C(NC(=O)c1ccccc1)C(C)P</smiles>

Scheme 3

Considering that the compounds prepared are $\beta, \beta-$ diarylamino acids that could be used as fluorescent markers, we decided to study the photophysical properties of some of the electrolysis products. The results obtained were compared with those of the corresponding dehydroalanines. Hence the absorption and emission properties of compounds $\mathbf{4 b}, \mathbf{4 c}, \mathbf{7 b}$ and 7c were studied in three solvents of different polarity (cyclohexane, acetonitrile and ethanol). The normalized absorption and fluorescence spectra of the four compounds are presented in Figures 1 and 2. The maximum absorption $\left(\lambda_{\mathrm{abs}}\right)$ and emission $\left(\lambda_{\text {em }}\right)$ wavelengths, molar absorption coefficients

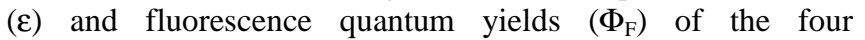
compounds are presented in Table 3.

The results obtained are consistent with the mechanism proposed for the reduction of $\alpha, \beta$-unsaturated ketones to give the corresponding saturated ketones in protic media. ${ }^{1}$ According to this mechanism the first step in the reduction of the $\beta, \beta$-diaryldehydroalanines would be the transfer of an electron to give the radical anion. This radical rapidly protonates and tautomerizes to give an alkyl radical that is more easily reduced than the reagent and is converted into the $\beta, \beta$ diarylalanine (Scheme 3). Although reported for $\alpha, \beta$ unsaturated ketones and esters, we did not detect the formation of dimers. This can be attributed to the sterical hindrance at the $\beta$-carbon atom of the $\beta, \beta$-disubstituted dehydroalanines, as reported by other authors for the reduction of norbornenedicarboxylate. 


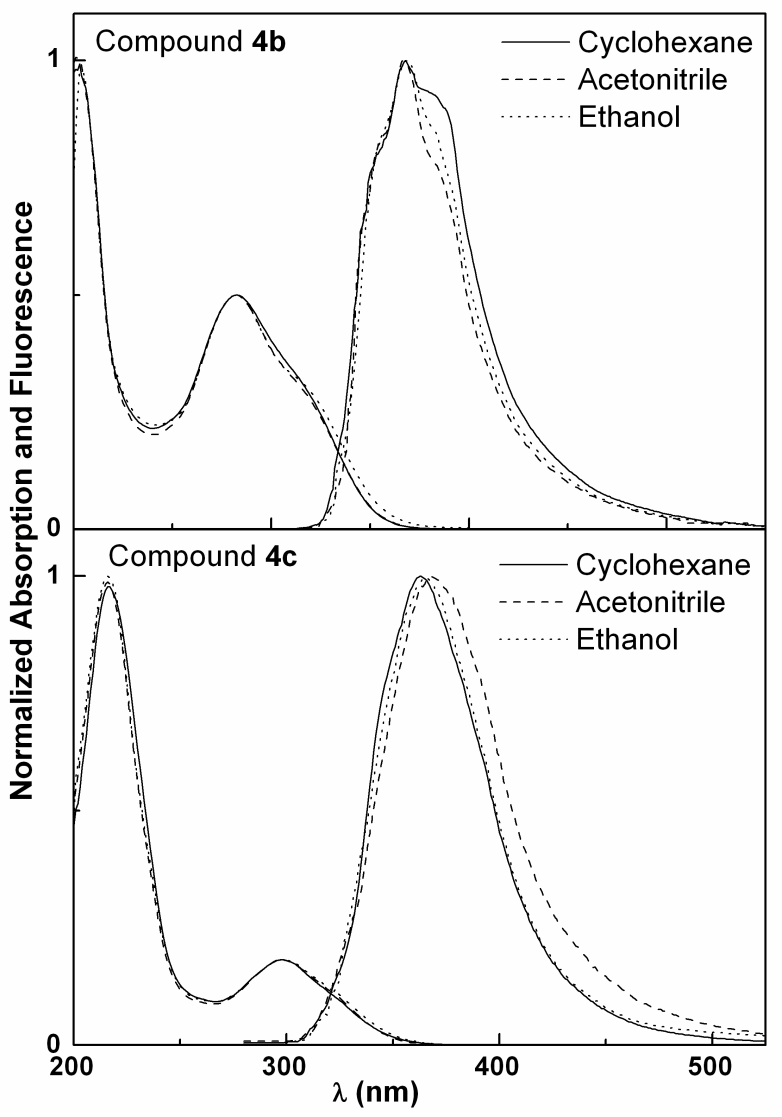

Figure 1. Normalized absorption (in the lowest energy band) and fluorescence spectra $\left(\lambda_{\text {exc }}=300 \mathrm{~nm}\right)$ of solutions $\left(2 \times 10^{-5}\right.$ mol.dm ${ }^{-3}$ for absorption and $2 \times 10^{-6}$ mol. $\mathrm{dm}^{-3}$ for fluorescence) of compounds $4 \mathbf{b}$ and $\mathbf{4 c}$ in several solvents.

These compounds present high molar absorption coefficients at the lowest energy band $\left(\varepsilon \geq 1.1 \times 10^{4} \mathrm{~mol}^{-1} \cdot \mathrm{dm}^{3} \cdot \mathrm{cm}^{-1}\right)$ in the three solvents studied (Table 3 ), pointing to $\pi \rightarrow \pi^{*}$ transitions. These $\varepsilon$ values are significantly lower for compounds $\mathbf{4 c}$ and $\mathbf{7 c}$ than for $\mathbf{4 b}$ and $\mathbf{7 b}$, due to the different chromophore groups present (two naphthyl groups in the former case and two biphenyl groups in the latter). In fact, biphenyl has a higher molar absorption coefficient than naphthalene $\left(\approx 16000 \mathrm{M}^{-1} . \mathrm{cm}\right.$ ${ }^{1}$ at $247.5 \mathrm{~nm}$ and $\approx 6000 \mathrm{M}^{-1} \mathrm{~cm}^{-1}$ at $275 \mathrm{~nm}$, respectively). ${ }^{10,11}$ A methyl ester group is present in all compounds and it is known that many carbonyl compounds present a low-lying $n \rightarrow \pi^{*}$ state. The $\pi \rightarrow \pi^{*}$ and $n \rightarrow \pi^{*}$ electronic transitions can be nearby in energy, resulting in state-mixing. ${ }^{12}$ The high values of the molar absorption coefficient can be explained by a predominance of $\pi \rightarrow \pi^{*}$ character in these compounds (Table $3)$.

The influence of the solvent in the absorption spectral shape is negligible for all compounds. The absence of the $\alpha, \beta$-double bond in compounds $\mathbf{7 b}$ and $\mathbf{7 c}$, which does not allow conjugation between the aromatic moieties and with the carbonyl group, causes a shift of the lowest energy absorption band to lower wavelengths, when compared with $\mathbf{4 b}$ and $\mathbf{4 c}$, respectively (Figures 1 and 2).

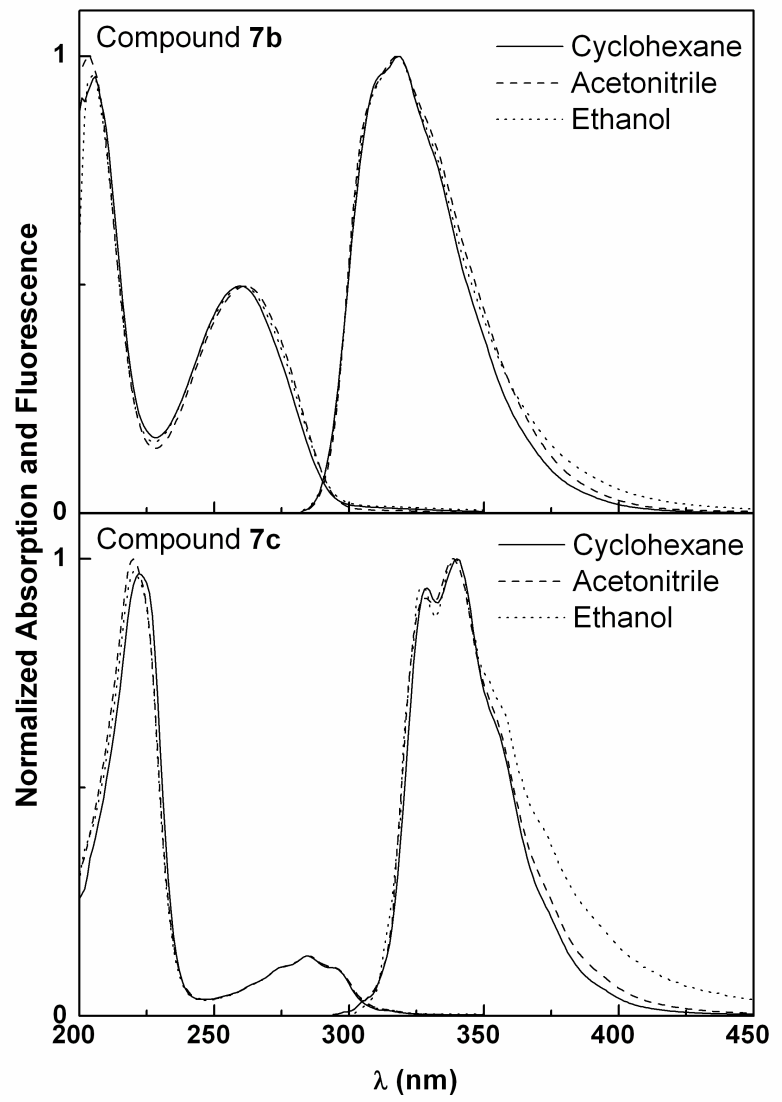

Figure 2. Normalized absorption (in the lowest energy band) and fluorescence spectra $\left(\lambda_{\text {exc }}=270 \mathrm{~nm}\right)$ of solutions $\left(2 \times 10^{-5}\right.$ mol.dm ${ }^{-3}$ for absorption and $2 \times 10^{-6}$ mol.dm ${ }^{-3}$ for fluorescence) of compounds $7 \mathbf{b}$ and $7 \mathbf{c}$ in several solvents.

The emission bands of the $\beta, \beta$-disubstituted dehydroalanines (4b and 4c) are located at lower energies than the corresponding $\beta, \beta$-diarylalanine compounds (7b and $\mathbf{7 c}$ ). A band enlargement and loss of vibrational structure is observed for $\mathbf{4 b}$ and $\mathbf{4 c}$ and also for compound $\mathbf{7 b}$ (Figures 1 and 2).

Compounds $\mathbf{4 b}$ and $\mathbf{4 c}$ present low fluorescence quantum yields $\left(\Phi_{\mathrm{F}}<9 \%\right.$, Table 3$)$. The conjugation of the dehydroamino acid double bond with the aromatic electrons of the $\pi$-systems (two biphenyl groups in $\mathbf{4 b}$ and two naphthyl moieties in the case of $\mathbf{4 c}$ ) and with the carbonyl group favours the non-radiative deactivation pathways. For the $\beta, \beta$ diarylalanines $\mathbf{7 b}$ and $\mathbf{7 c}$ the fluorescence quantum yield values increase significantly, due to the suppression of the conjugation, especially for compound $\mathbf{7 b}$. Compound $\mathbf{7 c}$ exhibits absorption and emission spectra that roughly resemble those of naphthalene. ${ }^{11}$

Some charge transfer (CT) character of the excited state is possible to occur, the conjugated $\mathrm{NH}$ group acting as the electron donor and the aromatic moieties as acceptors. A strong excited state CT was observed in pyrene-dimethylaniline derivatives. $^{14,15}$ However, in these compounds, the electronwithdrawing properties of the tert-butoxycarbonyl and of the methyl ester groups may contribute to a decrease in the CT character.

From $a b$ initio molecular quantum chemistry calculations, obtained with Gaussian 09 software $^{16}$ and use of a 3-21+G(d) basis set, ${ }^{17}$ the optimized geometries of compounds $\mathbf{4 b}, \mathbf{4 c}, \mathbf{7 b}$ and $7 \mathbf{c}$ were obtained (Figure 3 ). In compounds with the $\alpha, \beta$ - 
double bond $(\mathbf{4 b}, \mathbf{4 c})$ the two aromatic substituents are roughly perpendicular to each other. In compounds $\mathbf{7 b}$ and $\mathbf{7 c}$ there is a change in the relative position of the two aromatic moieties.

Table 3. Maximum absorption $\left(\lambda_{\text {abs }}\right)$ and emission wavelengths $\left(\lambda_{\mathrm{em}}\right)$, molar absorption coefficients $(\varepsilon)$ and fluorescence quantum yields $\left(\Phi_{\mathrm{F}}\right)$ for compounds $\mathbf{4 b}, \mathbf{4 c}, \mathbf{7 b}$ and $\mathbf{7 c}$.

\begin{tabular}{|c|c|c|c|c|c|c|c|c|c|c|c|c|}
\hline \multirow{2}{*}{ Solvent } & \multicolumn{4}{|c|}{$\lambda_{\mathrm{abs}}(\mathrm{nm})\left(\varepsilon / 10^{4} \mathrm{M}^{-1} \mathrm{~cm}^{-1}\right)$} & \multicolumn{4}{|c|}{$\lambda_{\mathrm{em}}(\mathrm{nm})$} & \multicolumn{4}{|c|}{$\Phi_{\mathrm{F}}^{\mathrm{a}}$} \\
\hline & $4 b$ & $4 c$ & $7 \mathbf{b}$ & $7 \mathrm{c}$ & $4 b$ & $4 c$ & $7 b$ & $7 c$ & $4 b$ & $4 c$ & $7 \mathrm{~b}$ & $7 \mathrm{c}$ \\
\hline Cyclohexane & $\begin{array}{l}283(3.21) \\
203(6.38)\end{array}$ & $\begin{array}{l}298(1.47) \\
216(7.90)\end{array}$ & $\begin{array}{l}260(3.32) \\
206(6.39)\end{array}$ & $\begin{array}{l}296(0.87) s h \\
285(1.12) \\
274(0.90) s h \\
222(8.27)\end{array}$ & $\begin{array}{c}368 \\
382 s h\end{array}$ & 363 & 318 & $\begin{array}{l}328 \\
339\end{array}$ & 0.067 & 0.086 & 0.37 & 0.13 \\
\hline Acetonitrile & $\begin{array}{l}281(3.41) \\
204(6.06)\end{array}$ & $\begin{array}{l}297(1.54) \\
216(8.39)\end{array}$ & $\begin{array}{l}262(3.45) \\
203(6.93)\end{array}$ & $\begin{array}{l}295(0.90) s h \\
285(1.12) \\
275(0.91) s h \\
220(8.52)\end{array}$ & $\begin{array}{c}368 \\
385 s h\end{array}$ & 367 & 318 & $\begin{array}{l}328 \\
339\end{array}$ & 0.025 & 0.044 & 0.32 & 0.15 \\
\hline Ethanol & $\begin{array}{l}281(3.09) \\
201(6.87)\end{array}$ & $\begin{array}{l}298(1.51) \\
216(8.31)\end{array}$ & $\begin{array}{l}261(3.41) \\
205(6.56)\end{array}$ & $\begin{array}{l}295(0.91) s h \\
285(1.14) \\
275(0.93) s h \\
220(8.45)\end{array}$ & $\begin{array}{c}369 \\
387 s h\end{array}$ & 365 & 319 & $\begin{array}{l}327 \\
339\end{array}$ & 0.043 & 0.035 & 0.40 & 0.23 \\
\hline
\end{tabular}

\footnotetext{
${ }^{\mathrm{a}}$ Relative to anthracene in ethanol $\left(\Phi=0.27\right.$ at $\left.25^{\circ} \mathrm{C}\right){ }^{13}$ for $\mathbf{3 b}$ and $\mathbf{3 c}$; relative to naphthalene in cyclohexane $\left(\Phi_{\mathrm{F}}=0.23\right.$ at 25 $\left.{ }^{\circ} \mathrm{C}\right) .{ }^{[11]} ; s h$ : shoulder.
}

Figures 4 and 5 display the representation of HOMO and LUMO molecular orbitals for the same four compounds. In both compounds $\mathbf{4 b}$ and $\mathbf{4 c}$ (Figure 4), the HOMO-LUMO transition causes a significant increase in the electronic density of the carbonyl group of the methyl carboxylate substituent, more significant for 4c. It can also be observed that the tertbutoxycarbonyl moiety does not participate in the HOMOLUMO transition of these two compounds.

In compound 4c, the HOMO-LUMO transition implies notable differences in the electronic density of the naphthyl substituents (Figure 4, below), with a charge transfer from one naphthyl to the other and a decrease in the electronic density of the nitrogen atom, confirming the significant charge transfer (CT) character of the excited state. This can justify the complete loss of vibrational structure in the fluorescence emission of compound $4 \mathbf{c}$, together with the red shift in polar solvents $(4 \mathrm{~nm}$ between cyclohexane and acetonitrile, Figure 1). A similar behaviour (with a significant loss of vibrational structure in the emission bands) was already observed for another $\beta, \beta$ diaryldehydroalanine, the methyl (Z)-2-[(tert-butoxycarbonyl)-3phenyl-3-pyren-1-yl]acrylate that exhibits a strong conjugation between adjacent aromatic moieties. ${ }^{18}$
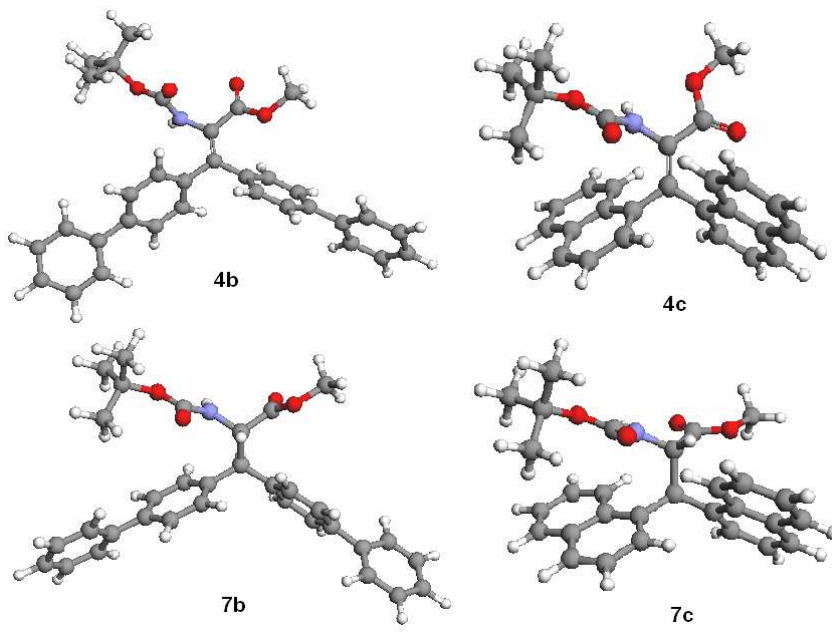

$4 \mathrm{c}$

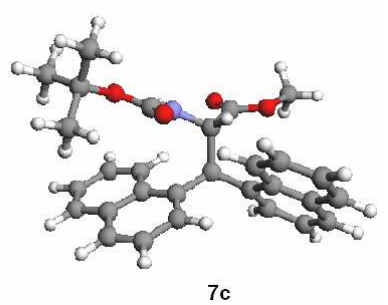

Figure 3. Optimized geometries of compounds $\mathbf{4 b}, \mathbf{4 c}, \mathbf{7 b}$ and $\mathbf{7 c}$ obtained by Gaussian 09 software (grey: $\mathrm{C}$ atoms; white: $\mathrm{H}$ atoms; red: $\mathrm{O}$ atoms; blue: $\mathrm{N}$ atoms).

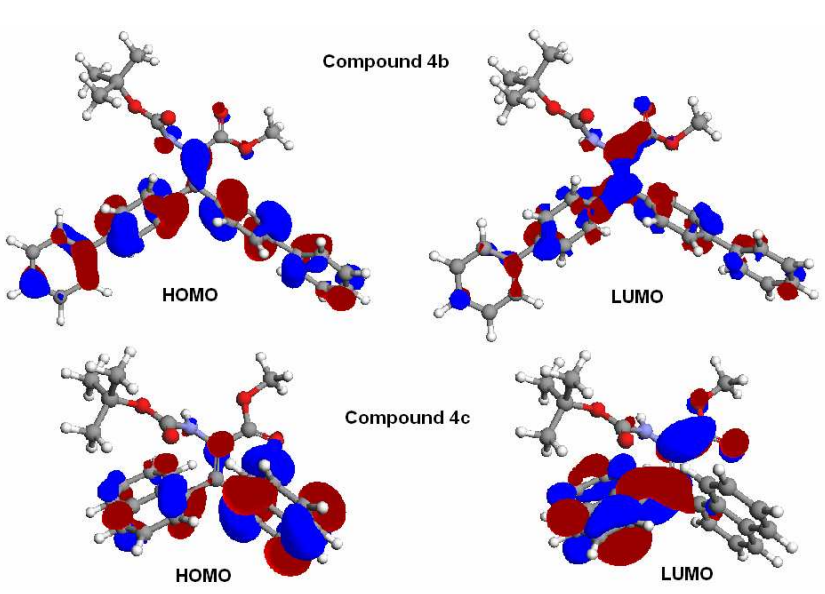

Figure 4. Representation of HOMO and LUMO molecular orbitals of compounds $\mathbf{4 b}$ (above) and $\mathbf{4 c}$ (below).

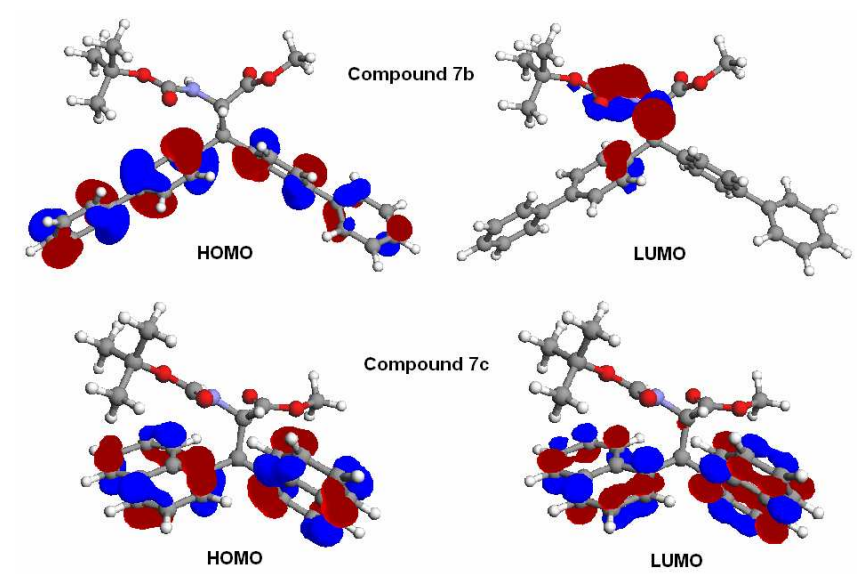

Figure 5. Representation of HOMO and LUMO molecular orbitals of compounds $\mathbf{7 b}$ (above) and $\mathbf{7 c}$ (below).

The HOMO-LUMO transition of compound $7 \mathbf{b}$ (Figure 5, above) causes strong changes in the electron density of several atoms of this molecule. While the HOMO is completely located at both biphenyl groups, upon HOMO-LUMO transition there is a charge transfer from the biphenyls to the $\alpha$-carbon and nitrogen atoms and also to the carbonyl of Boc group. This charge transfer justifies the almost complete loss of vibrational structure in fluorescence emission. 
A completely different feature is observed for the HOMO and LUMO orbitals of compound 7c (Figure 5), that are completely localized in the naphthyl moieties. For this reason, both absorption and fluorescence spectra of this molecule are similar to those of naphthalene ( $v d$. Figure 2).

The fluorescence studies reported here show that the latter two compounds (7b and $\mathbf{7 c}$ ), due to their reasonable fluorescence quantum yields and distinct photophysical behaviour, can be useful as fluorescent markers.

\section{Conclusions}

The electrochemical behaviour of several $\beta, \beta$ diaryldehydroalanine derivatives was studied by cyclic voltammetry. The cathodic peak potentials showed that these compounds can be considered activated alkenes and thus could be electrochemically reduced. Controlled potential electrolysis in the presence of an excess of a proton donor afforded the corresponding $\beta, \beta$-diarylalanines in good to high yields. The electrochemical reduction of the $\alpha, \beta$-double bond of dehydroamino acids constitutes an alternative to the conventional chemical methods which use metals as catalysts.

The photopysical properties of two of the $\beta, \beta$-disubstituted dehydroalanines and of the corresponding reduction products were studied. It was found that although the dehydroalanines show low quantum yields their reduction products show reasonably high fluorescent yields and could be useful as fluorescent markers.

In summary, we have developed a new methodology for the synthesis of $\beta, \beta$-diarylalanines from brominated dehydroalanines using a sequential Suzuki-Miyaura cross-coupling followed by the electrochemical reduction of the $\alpha, \beta$-double bond.

\section{Experimental Section}

Melting points $\left({ }^{\circ} \mathrm{C}\right)$ were determined in a Gallenkamp apparatus and are uncorrected. ${ }^{1} \mathrm{H}$ and ${ }^{13} \mathrm{C}$ NMR spectra were recorded on a Varian Unity Plus at 300 and $75.4 \mathrm{MHz}$, respectively or on a Bruker Avance $\mathrm{II}^{+}$at 400 and $100.6 \mathrm{MHz}$, respectively. ${ }^{1} \mathrm{H}-{ }^{1} \mathrm{H}$ spin-spin decoupling and DEPT $\theta 45^{\circ}$ were used. Chemical shifts are given in ppm and coupling constants in Hz. MS and HRMS data were recorded by the mass spectrometry service of the University of Vigo, Spain; elemental analysis was performed on a LECO CHNS 932 elemental analyser.

The reactions were monitored by thin layer chromatography (TLC). Column chromatography was performed on MachereyNagel silica gel 230-400 mesh. Petroleum ether refers to the boiling range $40-60{ }^{\circ} \mathrm{C}$. When solvent gradient was used, the increase of polarity was made from neat petroleum ether to mixtures of diethyl ether/petroleum ether, increasing $10 \%$ of diethyl ether each time until the isolation of the product.

Cyclic voltammetry experiments were carried out using a HiTek potentiostat type DT 2101, and a Hi-Tek wave generator type PPR1, connected to a Philips recorder type PM 8043 and to a three electrode, home-built glass cell. For controlled potential electrolyses the electrochemical cell was a conventional twocompartment, three-electrode, home-built batch cells of the type illustrated elsewhere. ${ }^{[19]}$

Spectroscopic measurements: All the solutions were prepared using spectroscopic grade solvents. Absorption spectra were recorded in a Shimadzu UV-3101PC UV-Vis-NIR spectrophotometer. Fluorescence measurements were performed using a Fluorolog 3 spectrofluorimeter, equipped with double monochromators in both excitation and emission and a temperature controlled cuvette holder. Fluorescence spectra were corrected for the instrumental response of the system.

Fluorescence quantum yields: For fluorescence quantum yield determination, the solutions were previously bubbled for 30 minutes with ultrapure nitrogen. The fluorescence quantum yields $\left(\Phi_{\mathrm{s}}\right)$ were determined using the standard method (equation $1),{ }^{19}$

$$
\Phi_{\mathrm{S}}=\frac{A_{\mathrm{r}} F_{\mathrm{S}} n_{\mathrm{S}}^{2}}{A_{\mathrm{s}} F_{\mathrm{r}} n_{\mathrm{r}}^{2}} \Phi_{\mathrm{r}}
$$

where $A$ is the absorbance at the excitation wavelength, $F$ the integrated emission area and $n$ the refraction index of the solvents used. Subscripts refer to the reference (r) or sample (s) compound.

\subsection{Synthesis of compounds 1, 2 and 3:}

The synthesis of compounds $\mathbf{1}^{7}, \mathbf{2}^{3 \mathrm{~d}}$ and $\mathbf{3}^{5}$ was described elsewhere.

\subsection{General Procedure for the Synthesis of $\beta, \beta$ - diaryldehydroamino acid derivatives}

To a solution of the $\tilde{\beta}$ brominated dehydroamino acid derivative in $\mathrm{THF} / \mathrm{H}_{2} \mathrm{O}(1: 1)$ the boronic acid, $\mathrm{PdCl}_{2} \mathrm{dppf} \cdot \mathrm{CH}_{2} \mathrm{Cl}_{2}$ (1:1) (10 mol-\%) and $\mathrm{Cs}_{2} \mathrm{CO}_{3}$ (1.4 equiv.) were added. The reaction mixture was heated at $90{ }^{\circ} \mathrm{C}$, and the reaction was monitored by TLC until all the $\beta, \beta$-dibromodehydroalanine derivative was consumed (1-3 h). The solvent was removed under reduced pressure, and the residue was dissolved in ethyl acetate $(100 \mathrm{~mL})$. The organic layer was washed with water and brine $(2 \times 30 \mathrm{~mL}$ each $)$, dried with $\mathrm{MgSO}_{4}$, and the solvent was removed. The residue was submitted to column chromatography.

\subsubsection{Synthesis of compounds 4c, $4 d$ and $5 c$ :}

Synthesis of compounds $\mathbf{4 c}, \mathbf{4 d}$ and $\mathbf{5 c}$ was described elsewhere. $^{8}$

\subsubsection{Synthesis of methyl 2-(tert- \\ butoxycarbonylamino)-3,3-diphenylacrylate, $\mathbf{4 a}$ :}

The general procedure described above using compound $\mathbf{1}$ (160.3 $\mathrm{mg}, 0.45 \mathrm{mmol}$ ) and phenylboronic acid (3 equiv.) was followed to give $\mathbf{4 a}$ as a white solid (92.24 mg, 58\%). M.p. 122.0-123.0 ${ }^{\circ} \mathrm{C}$ (from diethyl ether/petroleum ether). ${ }^{1} \mathrm{H}$ NMR $\left(300 \mathrm{MHz}, \mathrm{CDCl}_{3}\right): 1.46$ (s, $\left.9 \mathrm{H}, \mathrm{CH}_{3} \mathrm{Boc}\right), 3.54$ (s, $3 \mathrm{H}, \mathrm{OCH}_{3}$ ), 6.06 (br. s, $1 \mathrm{H}, \mathrm{NH}), 7.11-7.14$ (m, $2 \mathrm{H}, \mathrm{ArH}), 7.22-7.40(\mathrm{~m}, 8$ $\mathrm{H}, \mathrm{ArH}) \mathrm{ppm} .{ }^{13} \mathrm{C} \mathrm{NMR}\left(100.6 \mathrm{MHz}, \mathrm{CDCl}_{3}\right): 28.15\left[\mathrm{C}\left(\mathrm{CH}_{3}\right)_{3}\right]$, $52.00\left(\mathrm{OCH}_{3}\right), 81.23\left[\mathrm{OC}\left(\mathrm{CH}_{3}\right)_{3}\right], 125.74(\mathrm{C}), 127.83(\mathrm{CH})$, $128.08(\mathrm{CH}), 128.30(\mathrm{CH}), 128.75(\mathrm{CH}), 129.14(\mathrm{CH}), 129.86$ (CH), 134.12 (C), 138.57 (C), 139.79 (C), 152.81 (C=O), 166.55 $(\mathrm{C}=\mathrm{O})$ ppm. ppm. Calcd for $\mathrm{C}_{21} \mathrm{H}_{23} \mathrm{NO}_{4}$ (353.42): $\mathrm{C}$ 71.37, $\mathrm{H}$ 6.56, N 3.96; found C 71.28, H 6.62, N 4.10.

\subsubsection{Synthesis of methyl 3,3-di(biphenyl-4-yl)-2- (tert-butoxycarbonylamino) acrylate, $\mathbf{4 b}$ :}

The general procedure described above using compound $\mathbf{1}$ (161.6 $\mathrm{mg}, 0.45 \mathrm{mmol}$ ) and biphenylboronic acid (3 equiv.) was followed to give $\mathbf{4 b}(184.3 \mathrm{mg}, 81 \%)$ as a white solid. M.p. 108.0-109.0 ${ }^{\circ} \mathrm{C}$ (from diethyl ether/petroleum ether). ${ }^{1} \mathrm{H}$ NMR (400 MHz, $\mathrm{CDCl}_{3}$ ): 1.49 (s, $\left.9 \mathrm{H}, \mathrm{CH}_{3} \mathrm{Boc}\right), 3.61$ (s, $3 \mathrm{H}, \mathrm{OCH}_{3}$ ), 6.18 (br. s, $1 \mathrm{H}, \mathrm{NH}), 7.25-7.27$ (m, $2 \mathrm{H}, \mathrm{ArH}), 7.34-7.41$ (m, 4 H, ArH), 7.44-7.49 (m, 4 H, ArH), 7.56-7.58 (m, 2 H, ArH), 7.62-7.65 (m, $6 \mathrm{H}, \mathrm{ArH}) \mathrm{ppm} .{ }^{13} \mathrm{C} \mathrm{NMR}\left(100.6 \mathrm{MHz}, \mathrm{CDCl}_{3}\right)$ : $28.16\left[\mathrm{C}\left(\mathrm{CH}_{3}\right)_{3}\right], 52.07\left(\mathrm{OCH}_{3}\right), 81.29\left[\mathrm{OC}\left(\mathrm{CH}_{3}\right)_{3}\right], 125.75(\mathrm{C})$, $126.74(\mathrm{CH}), 126.95(\mathrm{CH}), 127.00(\mathrm{CH}), 127.39(\mathrm{CH}), 127.44$ $(\mathrm{CH}), 127.65(\mathrm{CH}), 128.77(\mathrm{CH}), 128.86(\mathrm{CH}), 129.70(\mathrm{CH})$, 
$130.44(\mathrm{CH}), 133.16(\mathrm{C}), 137.46(\mathrm{C}), 138.74(\mathrm{C}), 140.20(\mathrm{C})$, 140.39 (C), 140.57 (C), 141.13 (C), $152.84(\mathrm{C}=\mathrm{O}), 166.59$ (C=O) ppm. Anal. Calcd for $\mathrm{C}_{33} \mathrm{H}_{31} \mathrm{NO}_{4}$ (505.61): C 78.39, H 6.18, N 2.77; found C 77.87, H 6.64, N 2.73.

4.2.4. Synthesis of $(S)$-methyl 2-(2-(tertbutoxycarbonylamino)-3-phenylpropanamido)-3,3diphenylacrylate, $6 \boldsymbol{a}$

The general procedure described above using compound $\mathbf{3}$ (226.5 mg, $0.45 \mathrm{mmol}$ ) and phenylboronic acid (1.5 equiv.) was followed to give $6 \mathbf{a}(176 \mathrm{mg}, 78 \%)$ as a white solid. M.p. 99.0$100.0{ }^{\circ} \mathrm{C}$ (from diethyl ether/petroleum ether). ${ }^{1} \mathrm{H}$ NMR (400 $\mathrm{MHz}, \mathrm{CDCl}_{3}$ ): 1.35 (s, $9 \mathrm{H}, \mathrm{CH}_{3} \mathrm{Boc}$ ), $3.10(\mathrm{~d} \mathrm{~J}=6.4 \mathrm{~Hz}, 2 \mathrm{H}$, $\mathrm{CH}_{2}$ ), 3.57 (s, $\left.3 \mathrm{H}, \mathrm{OCH}_{3}\right), 4.33-4.39$ (m, $\left.1 \mathrm{H}, \mathrm{CH}\right), 4.84$ (br. s, 1 $\mathrm{H}, \mathrm{NH}), 7.26-7.30(\mathrm{~m}, 16 \mathrm{H}, \mathrm{ArH}+\mathrm{NH})$ ppm. ${ }^{13} \mathrm{C} \mathrm{NMR}(100.6$ $\left.\mathrm{MHz}, \mathrm{CDCl}_{3}\right): \delta=28.17\left[\mathrm{C}\left(\mathrm{CH}_{3}\right)_{3}\right], 37.68\left(\mathrm{CH}_{2}\right), 52.07\left(\mathrm{OCH}_{3}\right)$, $55.45(\mathrm{CH}), 80.38\left[\mathrm{OC}\left(\mathrm{CH}_{3}\right)_{3}\right], 124.60(\mathrm{C}), 127.04(\mathrm{CH}), 128.10$ $(\mathrm{CH}), 128.11(\mathrm{CH}), 128.59(\mathrm{CH}), 128.72(\mathrm{CH}), 128.74(\mathrm{CH})$, $129.14(\mathrm{CH}), 129.48(\mathrm{CH}), 129.75(\mathrm{CH}), 136.18(\mathrm{C}), 136.28(\mathrm{C})$, 137.80 (C), 139.21 (C), $155.20(\mathrm{C}=\mathrm{O}), 165.91(\mathrm{C}=\mathrm{O}), 169.64$ $(\mathrm{C}=\mathrm{O})$ ppm. Anal. Calcd for $\mathrm{C}_{30} \mathrm{H}_{32} \mathrm{~N}_{2} \mathrm{O}_{5}$ (500.59): $\mathrm{C} 71.98, \mathrm{H}$ 6.44, N 5.60; found C 72.14, H 6.57, N 5.60.

\subsection{General procedure for the controlled potential electrolysis of $\beta$, $\beta$-diaryldehydroamino acids}

A solution of $\mathrm{Et}_{4} \mathrm{NCl}\left(0.1 \mathrm{~mol} \mathrm{dm}{ }^{-3}\right.$; supporting electrolyte $)$ and $\mathrm{Et}_{3} \mathrm{NHCl}\left(0.04 \mathrm{~mol} \mathrm{dm}^{-3}\right.$; proton donor) in acetonitrile was added to a three-electrode cell. To its cathodic compartment the $\beta, \beta$-diaryldehydroamino acid derivative was added and a cyclic voltammogram recorded. The potential was adjusted to a value $50 \mathrm{mV}$ more negative than that corresponding to the $\mathrm{CV}$ peak and the electrolysis started, the reaction being monitored by HPLC. When all starting material had disappeared, the content of the cathodic compartment was concentrated at reduced pressure and the residue partitioned between $100 \mathrm{~cm}^{3}$ of diethyl ether and $25 \mathrm{~cm}^{3}$ of water. The organic phase was washed with water and brine $\left(2 \times 25 \mathrm{~cm}^{3}\right.$ each). After drying over $\mathrm{MgSO}_{4}$ the extract was taken to dryness at reduced pressure.

\subsubsection{Controlled potential electrolysis of $\mathbf{4 a}$}

The general procedure described above using 4a $(74.8 \mathrm{mg}$, $0.212 \mathbf{m m o l}$ ) as substrate was followed to give $7 \mathbf{a}$ as a white solid (63.7 mg, $85 \%$ ). M.p. 89.0-90.0 ${ }^{\circ} \mathrm{C}$ (from diethyl ether/petroleum ether). ${ }^{1} \mathrm{H} \mathrm{NMR}\left(400 \mathrm{MHz}, \mathrm{CDCl}_{3}\right): 1.38$ (s, $9 \mathrm{H}$, $\left.\mathrm{CH}_{3} \mathrm{Boc}\right), 3.51\left(\mathrm{~s}, 3 \mathrm{H}, \mathrm{OCH}_{3}\right), 4.38(\mathrm{~d}, J=6.3 \mathrm{~Hz}, 1 \mathrm{H}, \beta \mathrm{CH})$, 4.85 (br. d, $J=6.3 \mathrm{~Hz}, 1 \mathrm{H}, \mathrm{NH}$ ), 5.08 (br. t, $J=6.6 \mathrm{~Hz}, 1 \mathrm{H}$, $\alpha \mathrm{CH}), 7.25-7.32(\mathrm{~m}, 10 \mathrm{H}, \mathrm{ArH}) \mathrm{ppm} .{ }^{13} \mathrm{C} \mathrm{NMR}(100.6 \mathrm{MHz}$, $\left.\mathrm{CDCl}_{3}\right): 28.18\left[\mathrm{C}\left(\mathrm{CH}_{3}\right)_{3}\right], 52.00\left(\mathrm{OCH}_{3}\right), 53.68(\mathrm{BCH}), 56.80$ $(\alpha \mathrm{CH}), 80.12\left[\mathrm{OC}\left(\mathrm{CH}_{3}\right)_{3}\right], 127.03(\mathrm{CH}), 127.14(\mathrm{CH}), 128.25$ $(\mathrm{CH}), 128.48(\mathrm{CH}), 128.58(\mathrm{CH}), 128.70(\mathrm{CH}), 139.58(\mathrm{C})$, $140.21(\mathrm{C}), 155.18(\mathrm{C}=\mathrm{O}), 172.65(\mathrm{C}=\mathrm{O}) \mathrm{ppm}$. Anal. Calcd for $\mathrm{C}_{21} \mathrm{H}_{25} \mathrm{NO}_{4}$ (355.43): C 70.96, H 7.09, N 3.94; found C 70.55, H 7.05, N 4.02 .

\subsubsection{Controlled potential electrolysis of $\mathbf{4 b}$}

The general procedure described above using $\mathbf{4 b}(63.5 \mathrm{mg}$, $0.126 \mathbf{m m o l}$ ) as substrate was followed to give $\mathbf{7 b}$ as a white solid (50.3 mg, 79\%). M.p. 162.0-163.0 ${ }^{\circ} \mathrm{C}$ (from diethyl ether/petroleum ether). ${ }^{1} \mathrm{H} \mathrm{NMR}\left(400 \mathrm{MHz}, \mathrm{CDCl}_{3}\right)$ : 1.39 (s, $9 \mathrm{H}$, $\left.\mathrm{CH}_{3} \mathrm{Boc}\right), 3.57\left(\mathrm{~s}, 3 \mathrm{H}, \mathrm{OCH}_{3}\right), 4.49(\mathrm{~d}, J=6.3 \mathrm{~Hz}, 1 \mathrm{H}, \beta \mathrm{CH})$, 4.93 (br. d, $J=6.6 \mathrm{~Hz}, 1 \mathrm{H}, \mathrm{NH}$ ), 5.17 (br. t, $J=6.6 \mathrm{~Hz}, 1 \mathrm{H}$, $\alpha \mathrm{CH}), 7.34-7.46(\mathrm{~m}, 10 \mathrm{H}, \mathrm{ArH}), 7.54-7.59$ (m, $8 \mathrm{H}, \mathrm{ArH}) \mathrm{ppm}$. ${ }^{13} \mathrm{C}$ NMR $\left(100.6 \mathrm{MHz}, \mathrm{CDCl}_{3}\right): 28.21\left[\mathrm{C}\left(\mathrm{CH}_{3}\right)_{3}\right], 52.13\left(\mathrm{OCH}_{3}\right)$, $53.08(\beta \mathrm{CH}), 56.80(\alpha \mathrm{CH}), 80.24\left[\mathrm{OC}\left(\mathrm{CH}_{3}\right)_{3}\right], 126.97(\mathrm{CH})$, $126.99(\mathrm{CH}), 127.22(\mathrm{CH}), 127.28(\mathrm{CH}), 127.32(\mathrm{CH}), 127.44$
$(\mathrm{CH}), 128.68(\mathrm{CH}), 128.74(\mathrm{CH}), 128.76(\mathrm{CH}), 129.04(\mathrm{CH})$, $129.73(\mathrm{CH}), 138.58(\mathrm{C}), 139.24(\mathrm{C}), 139.92$ (C), $140.11(\mathrm{C})$, $140.57(\mathrm{C}), 155.24(\mathrm{C}=\mathrm{O}), 172.62(\mathrm{C}=\mathrm{O}) \mathrm{ppm}$. Anal. Calcd for $\mathrm{C}_{33} \mathrm{H}_{33} \mathrm{NO}_{4}$ (507.63): C 78.08, H 6.55, N 2.76; found $\mathrm{C} 77.68, \mathrm{H}$ $6.51, \mathrm{~N} 2.84$.

\subsubsection{Controlled potential electrolysis of $\mathbf{4 c}$}

The general procedure described above using 4c (135.4 mg, $0.296 \mathbf{m m o l}$ ) as substrate was followed to give $7 \mathbf{c}$ of a colorless oil (109.6 mg, 81\%). The compound was purified by column chromatography using diethyl ether/petroleum ether $1 / 9$ and then $1 / 8$ as eluent. M.p. $55.0-56.0{ }^{\circ} \mathrm{C} .{ }^{1} \mathrm{H}$ NMR $\left(400 \mathrm{MHz}, \mathrm{CDCl}_{3}\right)$ : 1.34 (s, $9 \mathrm{H}, \mathrm{CH}_{3}$ Boc), 3.29 (s, $3 \mathrm{H}, \mathrm{OCH}_{3}$ ), 5.03 (br. d, $J=6.9$ $\mathrm{Hz}, 1 \mathrm{H}, \mathrm{NH}), 5.31$ (br. $\mathrm{t}, J=6.3 \mathrm{~Hz}, 1 \mathrm{H}, \alpha \mathrm{CH}), 6.12$ (d, $J=5.7$ $\mathrm{Hz}, 1 \mathrm{H}, \beta \mathrm{CH}), 7.41-7.48(\mathrm{~m}, 6 \mathrm{H}, \mathrm{ArH}), 7.53(\mathrm{~d}, J=5.1 \mathrm{~Hz}, 1$ $\mathrm{H}, \mathrm{ArH}$ ), 7.62 (br. d, $J=5.1 \mathrm{~Hz}, 1 \mathrm{H}, \mathrm{ArH}), 7.77$ (t, $J=6.3 \mathrm{~Hz}, 2$ $\mathrm{H}, \mathrm{ArH}), 7.84-7.88$ (m, $2 \mathrm{H}, \mathrm{ArH}), 8.10-8.18$ (m, $2 \mathrm{H}, \mathrm{ArH})$ ppm. 13C NMR (100.6 MHz, $\left.\mathrm{CDCl}_{3}\right): 28.13\left[\mathrm{C}\left(\mathrm{CH}_{3}\right)_{3}\right], 43.10$ $(\beta \mathrm{CH}), 52.08\left(\mathrm{OCH}_{3}\right), 57.01(\alpha \mathrm{CH}), 80.07\left[\mathrm{OC}\left(\mathrm{CH}_{3}\right)_{3}\right], 122.85$ $(\mathrm{CH}), 122.96(\mathrm{CH}), 125.26(\mathrm{CH}), 125.43(\mathrm{CH}), 125.51(\mathrm{CH})$, $125.62(\mathrm{CH}), 125.85(\mathrm{CH}), 126.26(\mathrm{CH}), 126.45(\mathrm{CH}), 126.61$ $(\mathrm{CH}), 127.85(\mathrm{CH}), 127.97(\mathrm{CH}), 128.99(\mathrm{CH}), 129.14(\mathrm{CH})$, 131.24 (C), 131.95 (C), 133.93 (C), 134.13 (C), 135.54 (C), $136.79(\mathrm{C}), 155.16(\mathrm{C}=\mathrm{O}), 172.67(\mathrm{C}=\mathrm{O}) \mathrm{ppm}$. Anal. Calcd for $\mathrm{C}_{29} \mathrm{H}_{29} \mathrm{NO}_{4}$ (455.54): C 76.46, H 6.42, N 3.07; found C 76.44, H 6.60, N 3.14 .

\subsubsection{Controlled potential electrolysis of $\mathbf{4 d}$}

The general procedure described above using 4d $(58.1 \mathrm{mg}$, $0.115 \mathbf{m m o l}$ ) as substrate was followed to give $\mathbf{7 d}$ as a white solid (45.4 mg, 78\%). The compound was purified by column chromatography using diethyl ether/petroleum ether $1 / 9$ and then 1/8 as eluent. M.p. $110.0-111.0{ }^{\circ} \mathrm{C} .{ }^{1} \mathrm{H}$ NMR (400 MHz, $\mathrm{CDCl}_{3}$ ): 1.34 (s, $\left.9 \mathrm{H}, \mathrm{CH}_{3} \mathrm{Boc}\right), 3.35$ (s, $\left.3 \mathrm{H}, \mathrm{OCH}_{3}\right), 3.35-3.37(\mathrm{~m}, 4 \mathrm{H}$, $2 \mathrm{CH}_{2}$ ), 5.00 (br d, $J=8.4 \mathrm{~Hz}, 1 \mathrm{H}, \mathrm{NH}$ ), 5.25 (br t, $J=7.5 \mathrm{~Hz}, 1$ $\mathrm{H}, \alpha \mathrm{CH})$, ), $5.87(\mathrm{~d}, J=6.9 \mathrm{~Hz}, 1 \mathrm{H}, \beta \mathrm{CH}), 7.21-7.25(\mathrm{~m}, 5 \mathrm{H}$, ArH), 7.34-7.43 (m, $2 \mathrm{H}, \mathrm{ArH}), 7.56-7.78$ (m, $3 \mathrm{H}, \mathrm{ArH}) \mathrm{ppm}$. ${ }^{13} \mathrm{C}$ NMR $\left(100.6 \mathrm{MHz}, \mathrm{CDCl}_{3}\right): 28.15\left[\mathrm{C}\left(\mathrm{CH}_{3}\right)_{3}\right], 29.82\left(\mathrm{CH}_{2}\right)$, $30.46\left(\mathrm{CH}_{2}\right), 42.40(\beta-\mathrm{CH}), 52.08\left(\mathrm{OCH}_{3}\right), 57.05(\alpha-\mathrm{CH}), 79.95$ $\left[\mathrm{OC}\left(\mathrm{CH}_{3}\right)_{3}\right], 118.57(\mathrm{CH}), 118.84(\mathrm{CH}), 118.97(\mathrm{CH}), 119.2$ $(\mathrm{CH}), 119.27(\mathrm{CH}), 126.95(\mathrm{CH}), 127.47(\mathrm{CH}), 127.97(\mathrm{CH})$, $128.21(\mathrm{CH}), 130.01(\mathrm{C}), 131.43(\mathrm{C}), 132.80$ (C), 139.49 (C), 139.71 (C), 145.25 (C), 145.45 (C), 146.46 (C), 146.70 (C), $155.30(\mathrm{C}=\mathrm{O}), 171.79(\mathrm{C}=\mathrm{O}) \mathrm{ppm}$. Anal. Calcd for $\mathrm{C}_{33} \mathrm{H}_{33} \mathrm{NO}_{4}$ (507.62): C 78.08, H 6.55, N 2.67; found C 77.88, H 6.91, N 2.72 .

\subsubsection{Controlled potential electrolysis of $\mathbf{5 c}$}

The general procedure described above using 5c (90.2 mg, $0.224 \mathrm{mmol}$ ) as substrate was followed to give $\mathbf{8 c}$ as 1:1 mixture of diastereomers $(68.4 \mathrm{mg}, 76 \%)$. The diastereomers were separated by column chromatography using diethyl ether/petroleum ether $1 / 5$ as eluent to give:

M.p. 134.0-135.0 ${ }^{\circ} \mathrm{C} .{ }^{1} \mathrm{H}$ NMR (300 MHz, $\left.\mathrm{CDCl}_{3}\right): 1.36$ (s, 9 $\mathrm{H}, \mathrm{CH}_{3} \mathrm{Boc}$ ), 3.43 (s, $3 \mathrm{H}, \mathrm{OCH}_{3}$ ), 4.93 (br. d, $J=7.8 \mathrm{~Hz}, 1 \mathrm{H}$, $\mathrm{NH}), 5.10-5.22(\mathrm{~m}, 2 \mathrm{H}, \alpha \mathrm{CH}+\beta \mathrm{CH}), 7.15-7.33(\mathrm{~m}, 5 \mathrm{H}, \mathrm{ArH})$, 7.42-7.56 (m, $3 \mathrm{H}, \mathrm{ArH}$ ), 7.67 (br. d, $J=6.9 \mathrm{~Hz}, 1 \mathrm{H}, \mathrm{ArH}), 7.78-$ $7.86(\mathrm{~m}, 2 \mathrm{H}, \mathrm{ArH}), 8.05-8.08(\mathrm{~m}, 1 \mathrm{H}, \mathrm{ArH}) \mathrm{ppm} .{ }^{13} \mathrm{C} \mathrm{NMR}$ $\left(100.6 \mathrm{MHz}, \mathrm{CDCl}_{3}\right): 28.17\left[\mathrm{C}\left(\mathrm{CH}_{3}\right)_{3}\right], 49.25(\mathrm{CH}), 51.95$ $\left(\mathrm{OCH}_{3}\right), 57.34(\mathrm{CH}), 80.14\left[\mathrm{OC}\left(\mathrm{CH}_{3}\right)_{3}\right], 123.15(\mathrm{CH}), 124.82$ $(\mathrm{CH}), 125.30(\mathrm{CH}), 125.55(\mathrm{CH}), 126.34(\mathrm{CH}), 127.17(\mathrm{CH})$, $127.92(\mathrm{CH}), 128.43(\mathrm{CH}), 128.52(\mathrm{CH}), 128.97(\mathrm{CH}), 132.01$ (C), 134.17 (C), 134.69 (C), 139.66 (C) 155.09 (C=O), 173.09 $(\mathrm{C}=\mathrm{O})$ ppm. Anal. Calcd for $\mathrm{C}_{25} \mathrm{H}_{27} \mathrm{NO}_{4}$ (405.49): $\mathrm{C} 74.05, \mathrm{H}$ 6.71, N 3.45; found C 73.89, H 6.75, N 3.55. 
Oil, ${ }^{1} \mathrm{H}$ NMR (400 MHz, $\mathrm{CDCl}_{3}$ ): 1.41 (s, $\left.9 \mathrm{H}, \mathrm{CH}_{3} \mathrm{Boc}\right), 3.56$ (s, $3 \mathrm{H}, \mathrm{OCH}_{3}$ ), 4.88 (br. d, $J=6.9 \mathrm{~Hz}, 1 \mathrm{H}, \mathrm{NH}$ ), 5.25 (br t, $J=$ $4.8 \mathrm{~Hz}, 1 \mathrm{H}, \alpha \mathrm{CH}), 5.33(\mathrm{~d}, J=4.8 \mathrm{~Hz}, 1 \mathrm{H}, \beta \mathrm{CH}), 7.22-7.31(\mathrm{~m}$, $5 \mathrm{H}, \mathrm{ArH}$ ), 7.41-7.51 (m, $3 \mathrm{H}, \mathrm{ArH}), 7.72$ (br. d, $J=5.4 \mathrm{~Hz}, 1 \mathrm{H}$, ArH), 7.78 (br d, $J=6.0 \mathrm{~Hz}, 1 \mathrm{H}, \mathrm{ArH}), 7.82-7.84(\mathrm{~m}, 1 \mathrm{H}, \mathrm{ArH})$, 7.97-7.99 (m, 1 H, ArH) ppm. ${ }^{13} \mathrm{C}$ NMR (100.6 MHz, $\left.\mathrm{CDCl}_{3}\right)$ : $28.22\left[\mathrm{C}\left(\mathrm{CH}_{3}\right)_{3}\right], 47.97(\mathrm{CH}), 52.25\left(\mathrm{OCH}_{3}\right), 57.04(\mathrm{CH}), 80.19$ $\left[\mathrm{OC}\left(\mathrm{CH}_{3}\right)_{3}\right], 123.52(\mathrm{CH}), 125.03(\mathrm{CH}), 125.34(\mathrm{CH}), 125.44$ $(\mathrm{CH}), 126.16(\mathrm{CH}), 127.21(\mathrm{CH}), 127.87(\mathrm{CH}), 128.68(\mathrm{CH})$, $128.76(\mathrm{CH}), 128.84(\mathrm{CH}), 131.41(\mathrm{C}), 133.99(\mathrm{C}), 136.32(\mathrm{C})$, $139.45(\mathrm{C}) 155.33(\mathrm{C}=\mathrm{O}), 172.54(\mathrm{C}=\mathrm{O}) \mathrm{ppm}$. Anal. Calcd for $\mathrm{C}_{25} \mathrm{H}_{27} \mathrm{NO}_{4}$ (405.49): C 74.05, $\mathrm{H} \mathrm{6.71,} \mathrm{N} \mathrm{3.45;} \mathrm{found} \mathrm{C} 74.61, \mathrm{H}$ $7.07, \mathrm{~N} 3.45$.

\subsubsection{Controlled potential electrolysis of $\mathbf{6 a}$}

The general procedure described above using $6 \mathbf{a}(75.0 \mathrm{mg}$, $0.15 \mathrm{mmol}$ ) as substrate was followed to give $\mathbf{9 a}$ as mixture of diastereomers (64.8 mg, $86 \%)$.

${ }^{1} \mathrm{H}$ NMR (300 MHz, $\mathrm{CDCl}_{3}$ ): $1.36\left(\mathrm{~s}, 9 \mathrm{H}, \mathrm{CH}_{3} \mathrm{Boc}\right), 2.89-$ $3.01\left(\mathrm{~m}, 2 \mathrm{H}, \mathrm{CH}_{2}\right), 3.48$ and $3.50\left(2 \mathrm{~s}, 3 \mathrm{H}, \mathrm{OCH}_{3}\right), 4.26-4.43(\mathrm{~m}$, $1 \mathrm{H}, \mathrm{CH}), 4.72$ and $4.90(2 \mathrm{br} \mathrm{s}, 1 \mathrm{H}, \mathrm{NH}), 5.33-5.37(\mathrm{~m}, 1 \mathrm{H}, \mathrm{CH})$, 6.22-6.27 (m, 1H, CH), 7.03-7.28 (m, $16 \mathrm{H}, \mathrm{ArH}+\mathrm{NH}) \mathrm{ppm} .{ }^{13} \mathrm{C}$

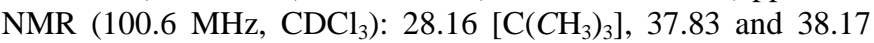
$\left(\mathrm{CH}_{2}\right), 52.10$ and $52.16\left(\mathrm{OCH}_{3}\right), 53.13$ and $53.72(\mathrm{CH}), 55.23$ and

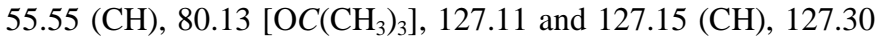
and $127.37(\mathrm{CH}), 128.15$ and $128.16(\mathrm{CH}), 128.45$ and 128.54 $(\mathrm{CH}), 128.55(\mathrm{CH}), 128.73(\mathrm{CH}), 128.74$ and $128.84(\mathrm{CH})$, 129.22 and $129.29(\mathrm{CH}), 136.43(\mathrm{C}), 139.16$ and $139.27(\mathrm{C})$, 139.82 and $139.87(\mathrm{C}), 155.14(\mathrm{C}=\mathrm{O}) 170.91$ and $171.13(\mathrm{C}=\mathrm{O})$, 171.54 and $171.66(\mathrm{C}=\mathrm{O}) \mathrm{ppm}$.

\section{Acknowledgments}

Foundation for the Science and Technology (FCT) - Portugal and FEDER (Fundo Europeu de Desenvolvimento Regional) for financial support to Centro de Química (CQ-UM) and Centro de Física (CFUM) of University of Minho and through research project PTDC/QUI/81238/2006, cofinanced by FCT and program FEDER/COMPETE (FCOMP-01-0124-FEDER-007467). The NMR spectrometer Bruker Avance II 400 is part of the National NMR Network and was purchased in the framework of the National Programme for Scientific Re-equipment, contract REDE/1517/RMN/2005, with funds from POCI 2010 (FEDER) and Fundação para a Ciência e a Tecnologia (FCT). G.P. acknowledges FCT for a PhD grant SFRH/BD/38766/2007.

\section{References}

1. Grishaw J. in Electrochemical Reactions and Mechanisms in Organic Chemistry, Elsevier Science B.V., The Netherlands, 2000, pp.54-89.

2. a) Zimmer, J.P.; Richards, J.A.; Turner, J. C.; Evans, D. H. Anal. Chem 1971, 43, 1000-1006; b) Annapoorna, S. R.; Prasada, M. J. Electroanal. Chem. 2000, 490, 93-97; c) Quintana-Espinoza, P.; Yanez, C.; Escobar, C. A.; Sicker, D.; Araya-Maturana, R.; Siquella, J. A. Electroanalysis 2006, 521-525; d) Pastor, F. T.; Drakulic B. J., Tetrahedron Lett. 2010, 51, 734-738.

3. a) Ferreira, P. M. T.; Maia, H. L. S.; Monteiro, L. S.; Sacramento, J.; Sebastião, J. J. Chem. Soc., Perkin Trans. 1 2000, 3317-3324. b) Ferreira, P. M. T.; Maia, H.L.S.; Monteiro, L.S.; Sacramento, J. J. Chem. Soc., Perkin Trans. 1 2001, 3167-3174. c) Ferreira, P. M. T.; Maia, H. L. S.; Monteiro, L. S. Eur. J. Org. Chem. 2003, 2635-2644. d) Abreu, A.S.; Ferreira, P. M.T.; Monteiro, L. S.; Queiroz, M. J. R. P.; Ferreira, I. C. F. R.; Calhelha, R. C.; Estevinho, L. M. Tetrahedron 2004, 60, 11821-11828. e) Ferreira, P. M. T.; Eur. J. Org. Chem. 2006, 3226-3234.

4. Ferreira, P. M. T.; Maia, H. L. S.; Monteiro, L. S. Tetrahedron Lett. 2003, 44, 2137-2139.
5. Ferreira, P. M. T.; Monteiro, L. S.; Pereira, G. Amino Acids 2010 , 39, 499-513.

6. a) Zhu, G.; Zhang, X.; J. Org. Chem., 1998, 63, 3133-3138; b) Giernoth, R.; Heinrich, H.; Adams, N. J.; Deeth, R. J.; Bargon, J.; Brown, J. M. J. Am. Chem. Soc. 2000, 122, 12381-12382; c) Ohashi, A.; Imamoto, T.Org. Lett. 2001, 3, 373-375; d) Shultz, C. S.; Dreher, S. D.; Ikemoto, N.; Williams, J. M.; Grabowski, E. J. J.; Krska, S.W.; Sun, Y.; Dormer, P.G.; DiMichele, L. Org. Lett. 2005, 7, 3405-3408.

7. Silva, N. O.; Abreu, A. S.; Ferreira, P. M. T.; Queiroz, M-J. R. P. Tetrahedron Lett. 2003, 44, 3377-3379.

8. Pereira, G.; Castanheira, E. M. S.; Ferreira, P. M. T.; Queiroz, MJ. R. P. Eur. J. Org. Chem. 2010, 464-475.

9. Sarrazin, J.; Tallec, A. Electrochim. Acta 1982, 27, 95-104.

10. Valeur, B. in Molecular Fluorescence - Principles and Applications, Wiley-VCH, Weinheim, 2001.

11. Berlman, I. B. in Handbook of Fluorescence Spectra of Aromatic Molecules, Academic Press, London, 1971.

12. Turro, N. J.; Scaiano, J. C.; Ramamurthy, V. in Modern Molecular Photochemistry of Organic Molecules, University Science Books, Sausalito (California), 2009.

13. a) Melhuish, W. H. J. Phys. Chem. 1961, 65, 229-235; b) Dawson, W. R.; Windsor, M. W. J. Phys. Chem. 1968, 72, 3251-3260.

14. Wiessner, A.; Hüttmann, G.; Kühnle, W.; Staerk, H. J. Phys. Chem. 1995, 99, 14923-14930.

15. Techert, S.; Schmatz, S.; Wiessner, A.; Staerk, H. J. Phys. Chem. A 2000, 104, 5700-5710.

16. Frisch, M. J.; Trucks, G. W.; Schlegel, H. B.; Scuseria, G. E.; Robb, M. A.; Cheeseman, J. R.; Scalmani, G.; Barone, V.; Mennucci, B.; Petersson, G. A.; Nakatsuji, H.; Caricato, M.; Li, X.; Hratchian, H. P.; Izmaylov, A. F.; Bloino, J.; Zheng, G.; Sonnenberg, J. L.; Hada, M.; Ehara, M.; Toyota, K.; Fukuda, R.; Hasegawa, J.; Ishida, M.; Nakajima, T.; Honda, Y.; Kitao, O.; Nakai, H.; Vreven, T.; Montgomery Jr., J. A.; Peralta, J. E.; Ogliaro, F.; Bearpark, M.; Heyd, J. J.; Brothers, E.; Kudin, K. N.; Staroverov, V. N.; Kobayashi, R.; Normand, J.; Raghavachari, K.; Rendell, A.; Burant, J. C.; Iyengar, S. S.; Tomasi, J.; Cossi, M.; Rega, N.; Millam, J. M.; Klene, M.; Knox, J. E.; Cross, J. B.; Bakken, V.; Adamo, C.; Jaramillo, J.; Gomperts, R.; Stratmann, R. E.; Yazyev, O.; Austin, A. J.; Cammi, R.; Pomelli, C.; Ochterski, J. W.; Martin, R. L.; Morokuma, K.; Zakrzewski, V. G.; Voth, G. A.; Salvador, P.; Dannenberg, J. J.; Dapprich, S.; Daniels, A. D.; Farkas, Ö.; Foresman, J. B.; Ortiz, J. V.; Cioslowski, J.; Fox, D. J. Gaussian, Inc., Wallingford CT, USA, 2009.

17. Jensen, F. in Introduction to Computational Chemistry, John Wiley \& Sons, West Sussex, England, 1999.

18. Abreu, A. S.; Castanheira, E. M. S.; Ferreira, P. M. T.; Monteiro, L. S.; Pereira, G.; Queiroz, M.-J. R. P. Eur. J. Org. Chem. 2008, 5697-5703.

19. a) Demas, J. N.; Crosby, G. A. J. Phys. Chem. 1971, 75, 9911024; b) Fery-Forgues, S.; Lavabre, D. J. Chem. Educ. 1999, 76, 1260-1264. 